\title{
On the Age of the Hominid Fossils at the Sima de los Huesos, Sierra de Atapuerca, Spain: Paleomagnetic Evidence
}

\author{
JOSEP M. PARÉS, ${ }^{1 *}$ ALFREDO PÉREZ-GONZALEZ, ${ }^{2}$ ARLO B. WEIL, ${ }^{1}$ \\ AND JUAN LUIS ARSUAGA ${ }^{3}$ \\ ${ }^{1}$ Department of Geological Sciences, University of Michigan, Ann Arbor, \\ Michigan 48109-1063 \\ ${ }^{2}$ Departamento de Geodinámica, Facultad de CC. Geológicas, Universidad \\ Complutense, 28040 Madrid, Spain.E-mail: alfredo@eucmax.sim.ucm.es \\ ${ }^{3}$ Departamento de Paleontología, Facultad de CC. Geológicas, \\ Universidad Complutense, 28040 Madrid, Spain. \\ E-mail:azara@eucmax.sim.ucm.es
}

KEY WORDS Middle Pleistocene; Neanderthal; Spain; remanent magnetization; Matuyama-Brunhes

\begin{abstract}
We report new paleomagnetic data for the Middle Pleistocene hominid-bearing strata in the Sima de los Huesos, North Spain. Sediments (brown muds with human and bear fossils and the underlying sterile clayey and sandy unit) preserve both normal and reversed magnetic components. The sterile unit has exclusively reversed magnetization, dating back to the Matuyama Chron, and thus is Lower Pleistocene in age. The overlying fossiliferous muds have a dominant normal magnetization that overprints a partially resolved reversed magnetization. These data are compatible with one of the reversal events that occurred during the Brunhes Chron. Combined with the existing U-series dates and evidence from the macro- and microfauna, these paleomagnetic results suggest an age of the hominid fossils between 325 to $205 \mathrm{ka}$, whereas the underlying sand and silts are older than 780 ka. Am J Phys Anthropol 111:451-461, 2000. ๑ 2000 Wiley-Liss, Inc.
\end{abstract}

The Sierra de Atapuerca in north central Spain contains a rich variety of karst fissures and cavities of a phreatic-vadose regime. Several caves of this karst system contain archaeological and paleontological remains that have been the focus of numerous studies since the 1980s (see Aguirre et al., 1990; Arsuaga et al., 1997 and references therein). In particular, the Sima de los Huesos has been systematically excavated since 1984 (see a review of the research in Journal of Human Evolution, 1997, v. 33). The Sima de los Huesos ("Pit of the Bones") hominids are the largest and best preserved sample of Middle Pleistocene humans from one site, and they are thought to document an early stage in Neanderthal evolution (Arsuaga et al., 1993). A detailed description of the geological and karst development of the paleontological site can be found in Pérez-González et al. (1995), Zazo et al. (1983), and Martin et al. (1981). The hominids have recently been dated by Bischoff et al. (1997), using U-series and ESR analyses, and these provide a minimum age of $284 \mathrm{ka}$. In addition, rodents (Cuenca-Bescós et al., 1997) give an age of Saalian (oxygen isotope stage; OIS 8-7), and the carnivore (Garcia et al., 1997) assemblage correlates with OIS 7 or older $(>200$ $\mathrm{ka}$ ), in agreement with the U-dating. We carried out a paleomagnetic study on the

Grant sponsor: Consejería de Cultura y Turismo (Junta de Castilla y León); Grant sponsor: DGES; Grant numbers: PB960815, PB96-1026-C03; Grant sponsor: Unidad Asociada CSICUCM.

*Correspondence to: Josep M. Parés, Department of Geological Sciences, University of Michigan, 2534 C.C. Little Building, Ann Arbor, MI 48109-1063. jmpares@umich.edu.

Received 14 May 1999; Accepted 7 December 1999. 

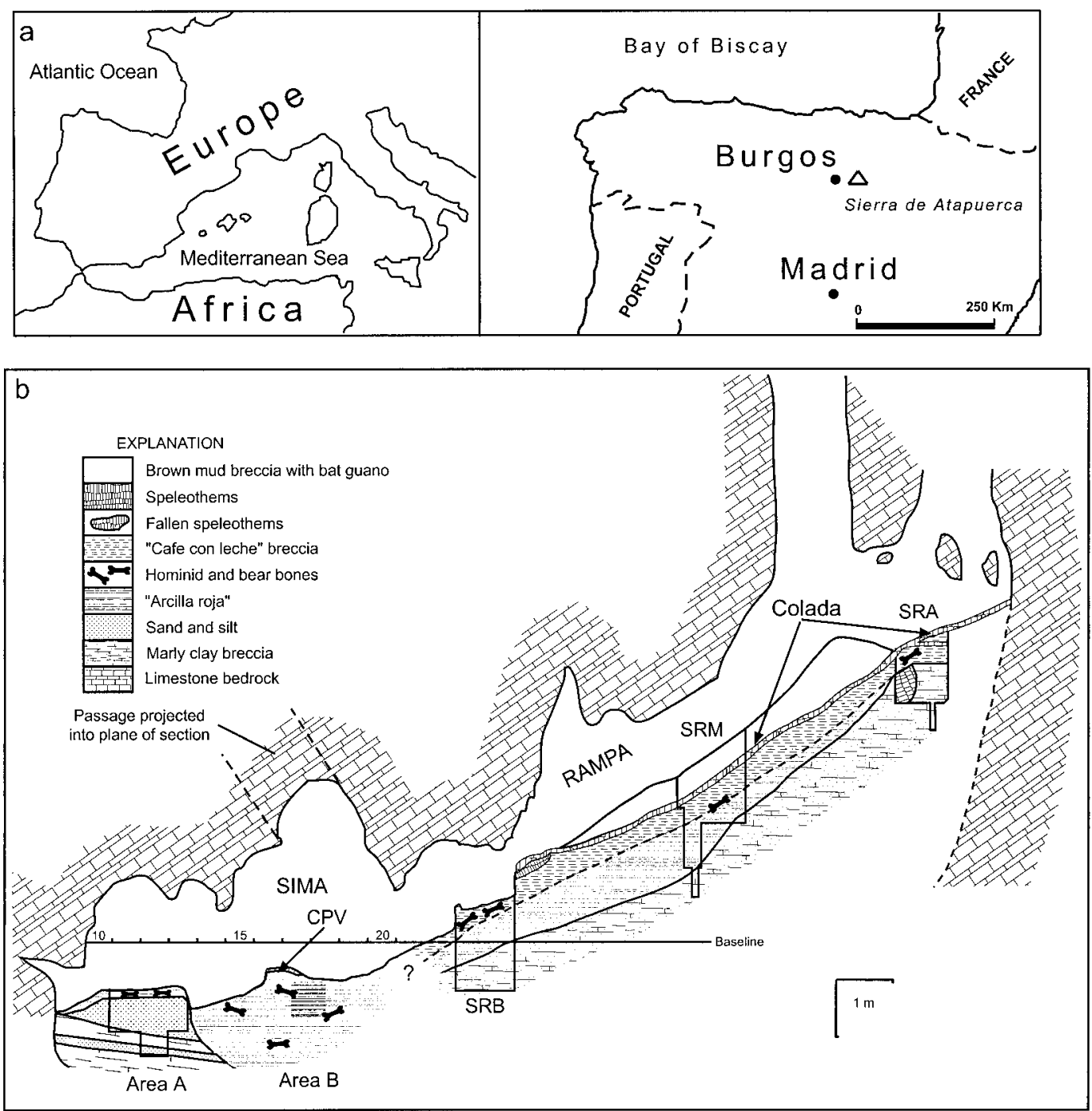

Fig. 1. a: Location of Atapuerca paleoanthropological site. b: Interpretive east-west cross section of the Sima de los Huesos according to Bischoff et al. (1997). The sections that are object of this study are areas A, B, and SRB. See text for details.

fossiliferous clay ("arcilla roja," matrix of the breccia of the human bones) and on the underlying deposits in order to establish the magnetic record and further constrain the age of the hominid fossils.

\section{GEOLOGICAL SETTING AND METHODS}

The Sierra de Atapuerca is made of Mesozoic limestones and is located at the northeastern border of the Iberian Meseta, in the Duero Basin, one of its Tertiary con- tinental basins (Fig. 1). The karst where the Atapuerca archaeological sites are located (Elefante, Galeria, Dolina, and Cueva Mayor) is developed in the Upper Cretaceous (Turonian-Santonian) limestones, and these represent a marine transgression of an inner platform of 45-70 m thickness. Unconformably overlying the Cretaceous limestones are calcareous conglomerates and red Oligocene sandstones (Olivé et al., 1990; Pineda and Arce, 1997). The Atapu- 
erca endokarst has a phreatic origin (e.g., Cueva Mayor) and is a covered karst (Torres, 1976), whose main development phase was synchronous to the sedimentation of the Aragonian or Middle Vallesian limestones (Zazo et al., 1983, 1987). According to these authors, Cueva Mayor and the caves of Galería, Dolina, and Elefante of the abandoned railway trench would be senile forms, along with terraces $\mathrm{T} 1$ and $\mathrm{T} 2$, presumably of Lower Pleistocene age.

The paleomagnetic sampling was carried out in two areas within the Sima de los Huesos (Fig.2). The site consists of a 2-4-mdiameter vertical shaft that extends downward $13 \mathrm{~m}$ to terminate at the top of a moderate ramp or "rampa" (for a more detailed description of the site, see Arsuaga et al., 1997; Bischoff et al., 1997). The ramp is a 9-m-long irregular linear chamber 1-2 m high by $2-3 \mathrm{~m}$ wide, inclined approximately $32^{\circ}$ to the northwest, with two excavated areas (areas A and B, Fig. 1) at its base. Area $\mathrm{A}$ is at the west edge of the ramp, and the stratigraphic section comprises two different levels: a lower level of semiconsolidated sand and silt, and an upper level of matrix-supported breccia of human bones and bear bones, and fragments of speleothem, known as "arcilla roja" (red clay) (Arsuaga et al., 1997; Bischoff et al., 1997). Area B, located at the north and at the foot of the ramp, has only the upper level of arcilla roja, which reaches up to $75 \mathrm{~cm}$ in thickness. In addition to areas $\mathrm{A}$ and $\mathrm{B}$, the middle part of section SRB was also sampled for paleomagnetism.

Clay and silt deposits at Sima de los Huesos are sufficiently soft that the samples could be obtained by simply hammering a brass tube with a reinforced stainless steel tip into the cleaned outcrop surface. A standard orientation device (compass-inclinometer) was used to measure the azimuth and dip of the in situ cylinders. Sediment samples were stored in cylindrical plastic boxes and were impregnated with a water solution of sodium silicate (1:1) for solidification.

Natural Remanent Magnetization (NRM) of the 30 samples was measured on two different SQUID magnetometers: 1) a GM400 three-axes magnetometer housed in a three-pair Helmholtz coil at the CSIC Pa- leomagnetic Laboratory in Barcelona, and 2) a $2 \mathrm{G}$ three-axes cryogenic magnetometer in the field-free room at the University of Michigan's paleomagnetic laboratory. The noise level of these magnetometers is 7 $\mu \mathrm{A} / \mathrm{m}$, well below the magnetization intensity of the measured samples. Standard cylindrical 2.54-cm paleomagnetic cores were progressively demagnetized in a TSD-1 furnace (Schonstedt in Barcelona and in an ASC Thermal Demagnetizer at the University of Michigan). Least-squares fits to the linear demagnetization trajectories for both the low- and the high-temperature components in each sample were made by principal components analysis (Kirschvink, 1980).

\section{RESULTS}

The initial intensity of the Natural Remanent magnetization ranged from 2.5-16 $\mathrm{mA} / \mathrm{m}$ for the silty and clayey sand underlying the fossiliferous mud, and from 2-17 $\mathrm{mA} / \mathrm{m}$ for the clays of the hominid-bearing arcilla roja. Representative orthogonal projection plots (Zijderveld, 1967), including normalized magnetization $\left(\mathrm{M}[\mathrm{T}] / \mathrm{M}\left[20^{\circ} \mathrm{C}\right]\right)$ plotted vs. demagnetization temperature, are presented in Figures $3-5$, and equal area projections of the characteristic remanent magnetization (ChRM) directions for the three separate sedimentary units are given in Figure 6. Sand and silt samples from the lower part of the section at area A and section SRB show two magnetic components upon thermal demagnetization (Fig. 3). A low-temperature (LT) component is unblocked at temperatures up to $250^{\circ} \mathrm{C}$ and often, but not always, has a northerly and downward direction, i.e., conforming to the present-day field. A high-temperature (HT) component is defined above $300^{\circ} \mathrm{C}$ with a southerly and upward direction, representative of a reversed geomagnetic field. This bicomponent behavior has been previously observed in other stratigraphic sections within the Atapuerca site and reveals that there has been a widespread secondary overprint by the Brunhes normal polarity chron on an HT component that is reversed (Parés and Pérez-González, 1995). The results for the arcilla roja at areas A and B are summarized in Figures 4 and 5. Stepwise progressive thermal demagnetization al- 

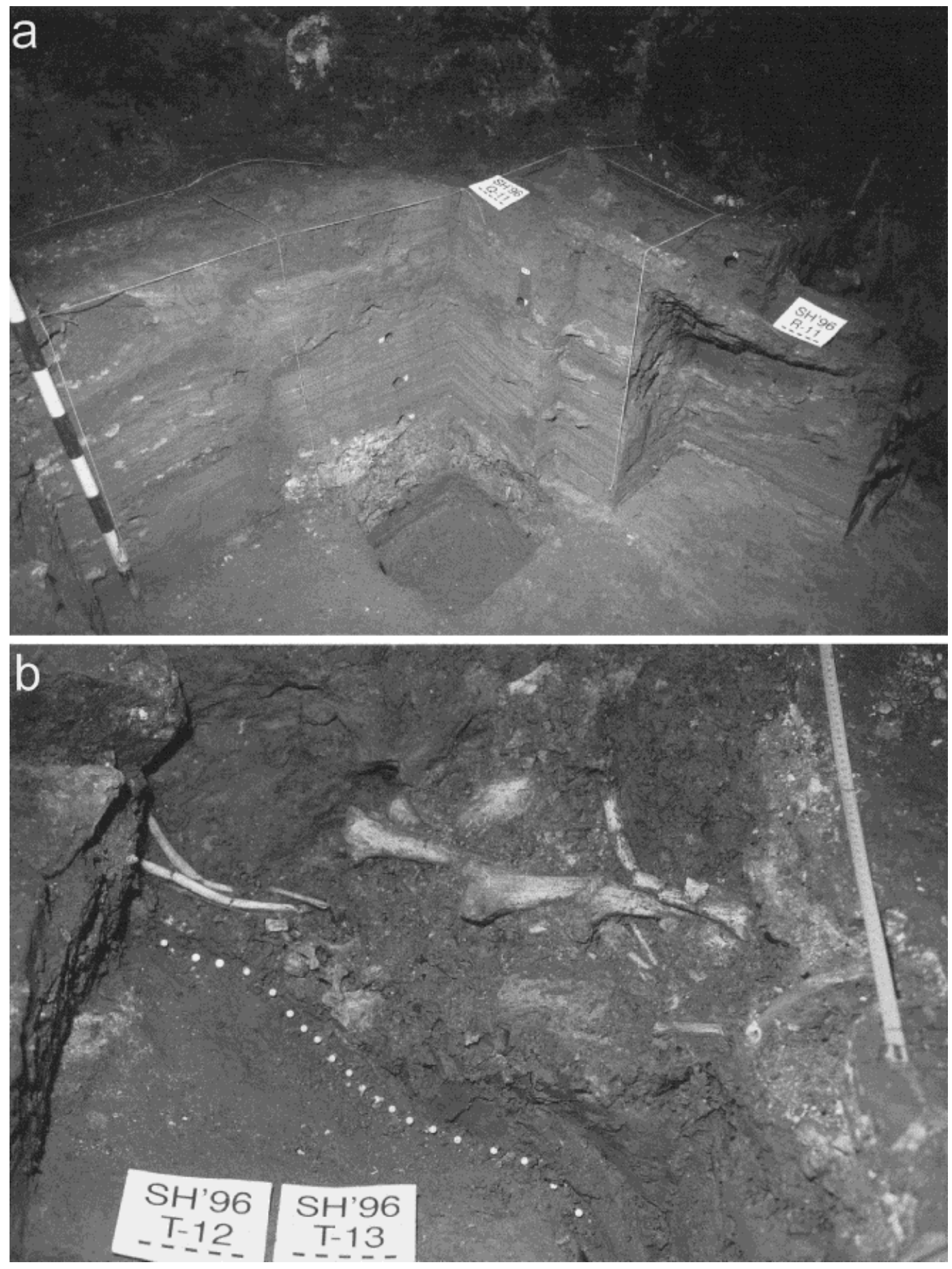

Fig. 2. View of the sedimentary record in the Sima de los Huesos. a: View to the west of area A, showing laminated sandy silts overlaid by the red clay unit ("arcilla roja"). The contact between these two units is erosional, and is marked by a clast of a plate of speleothem (at right). The red clays contain both human and bear bones, as well as fragments of speleothem. b: View to the northwest of area B, showing mud breccia of bear and human bones and contact (white dots) with underlying laminated sandy-silts. Photographs by Javier Trueba. 


\section{Sima de los Huesos - Sand and silt unit (Area A)}

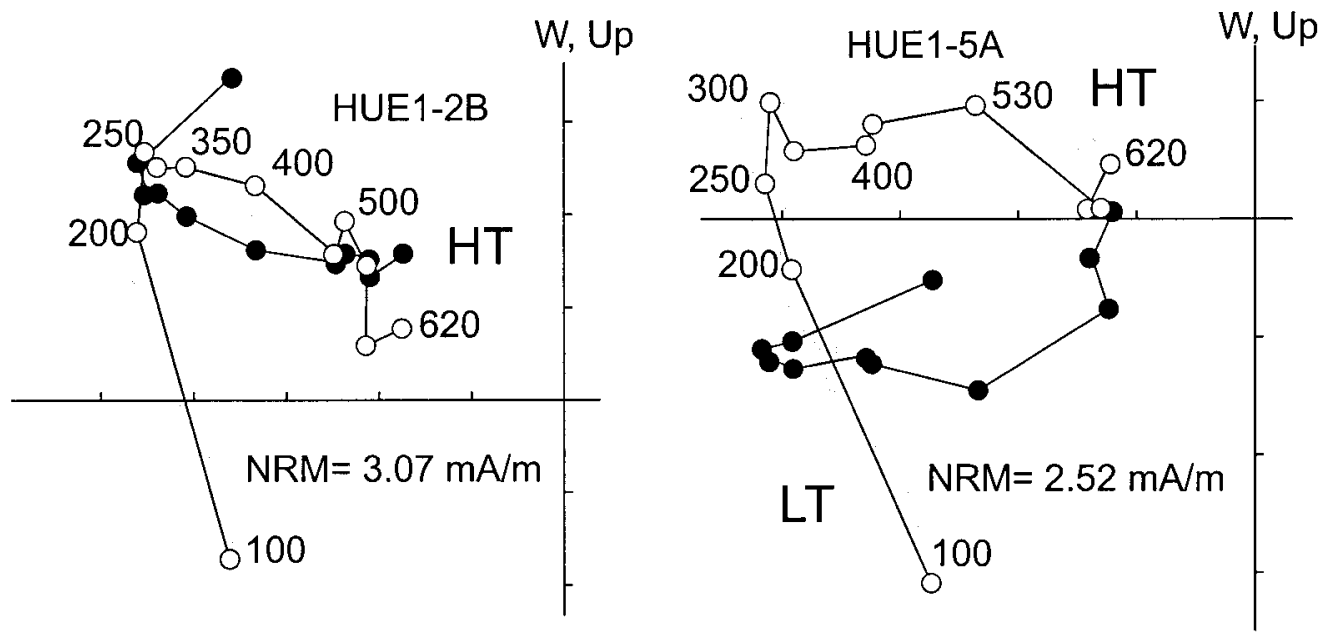

\section{Sima de los Huesos - Clay Breccia (SRB)}
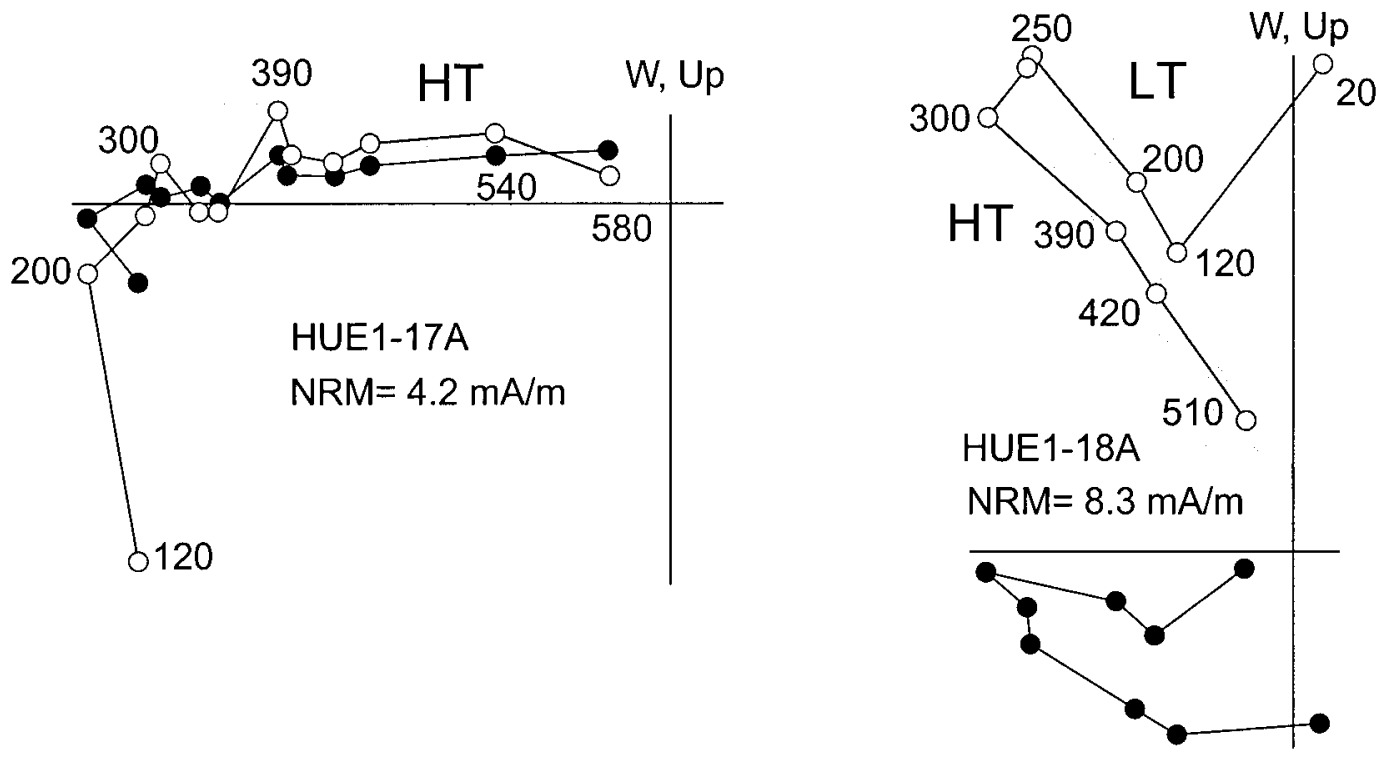

Fig. 3. Results of progressive thermal demagnetization displayed by vector end point diagrams (Zijderveld, 1967) of representative samples for the sand and silt of Area A. Each data point represents the natural remanent magnetization (NRM) end vector for individual demagnetization steps projected onto the horizontal (solid symbols) and vertical (open symbols) plane. Numbers adjacent to magnetization directions indicate the demagnetization temperatures in degrees Celsius. Initial value of magnetization intensity (NRM) is also shown. 


\section{Sima de los Huesos - Area A}
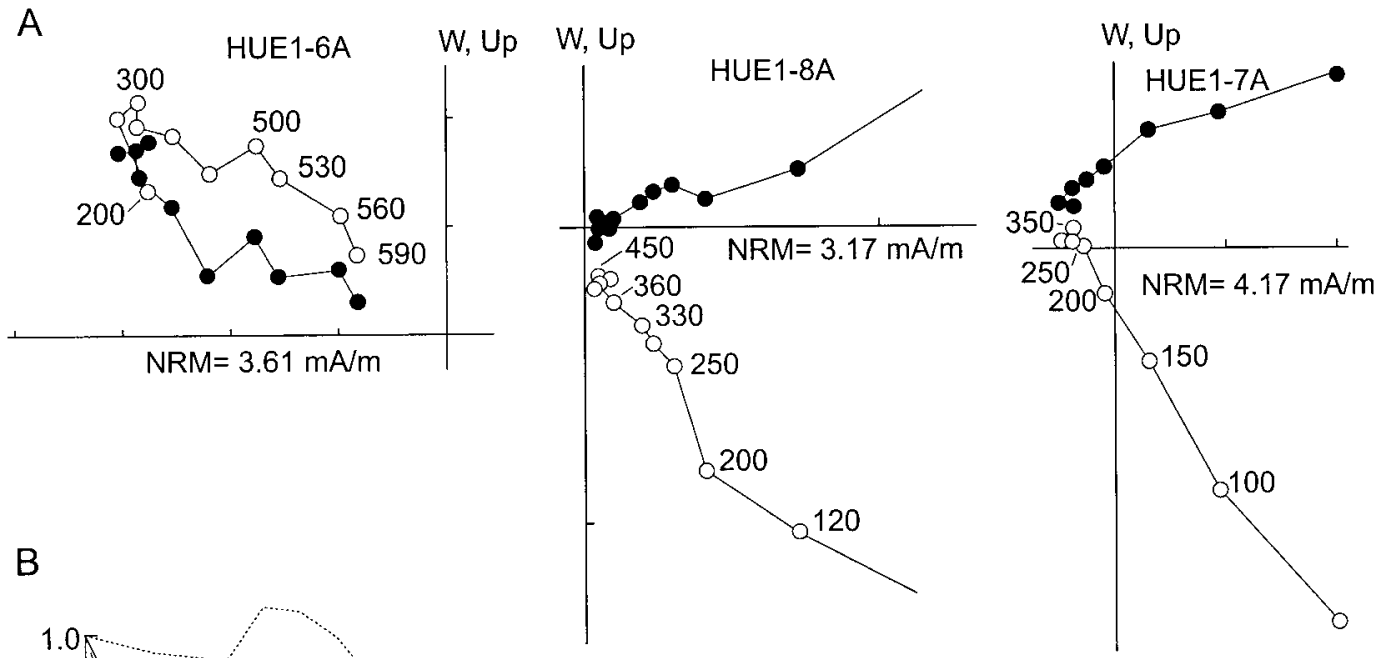

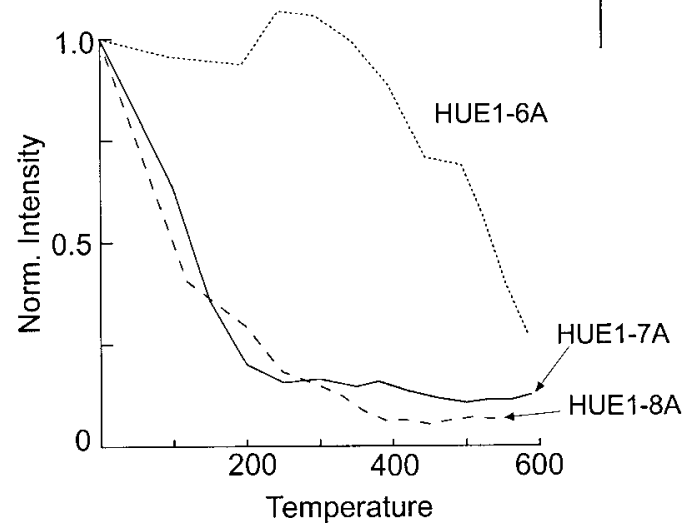

Fig. 4. A: Results of progressive thermal demagnetization of representative samples from clays of area A. Same symbols as in Fig. 3. B: Plot of the intensity decay curves during thermal treatment. Intensity is expressed as a normalized value $\left(\mathrm{M}[\mathrm{T}] / \mathrm{M}\left[20^{\circ} \mathrm{C}\right]\right)$. C: Equal-area, lower-hemisphere projection of demagneti-

lows us to distinguish two different types of behavior in the mud samples from the hominid breccia. The first set of samples is characterized by a sharp decrease of intensity up to $300^{\circ} \mathrm{C}$ that corresponds to a northerly and downward component on the orthogonal plots (Fig. 4, sample HUE1-8A; Fig. 5, sample HUE1-11A). The second set of samples also displays a relatively sharp decrease in intensity up to $300^{\circ} \mathrm{C}$; however, at this temperature there is still about $10-15 \%$ of the initial intensity left (Fig. 4, sample HUE17A; Fig. 5, sample HUE1-9B). Further increases in temperature failed to decrease zation end vectors for two samples. Note the convergence of the two great circles towards a south and upwards magnetization direction, revealing an unresolved high-temperature reversed magnetization (reference direction by Parés and Pérez-González, 1995). See text for details.

the intensity and resulted in a spurious magnetization above ca. $500^{\circ} \mathrm{C}$. The demagnetization paths on the orthogonal diagrams for this set of samples pass close to the origin, revealing that there is an unresolved high-temperature component which is masked by the LT component. The orthogonal projections indicate that this magnetization has reverse polarity: the path of the horizontal component of magnetization is directed towards the southern quadrant, whereas the vertical component tends to go to the upper hemisphere (i.e., negative). Only very few samples show a high-temper- 
Sima de los Huesos - Area B

A

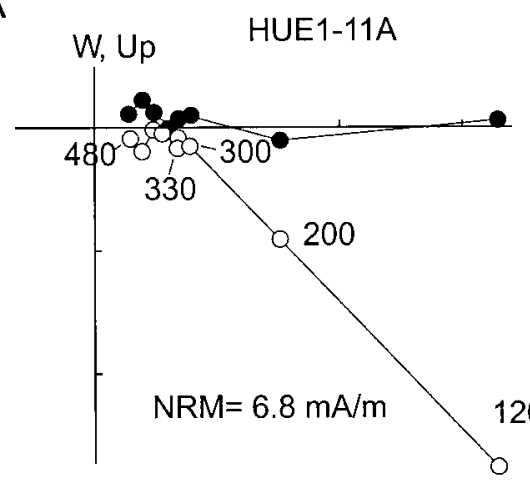

B

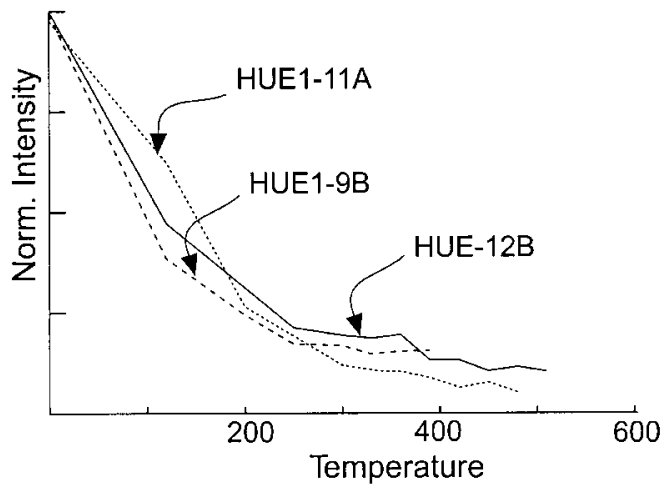

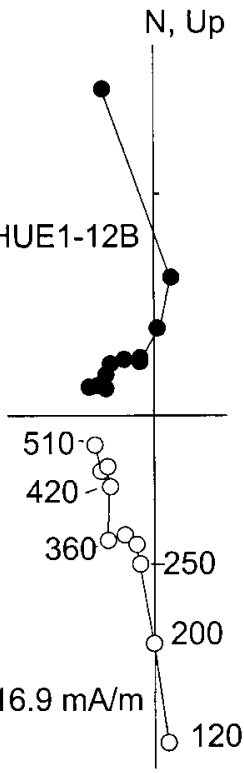

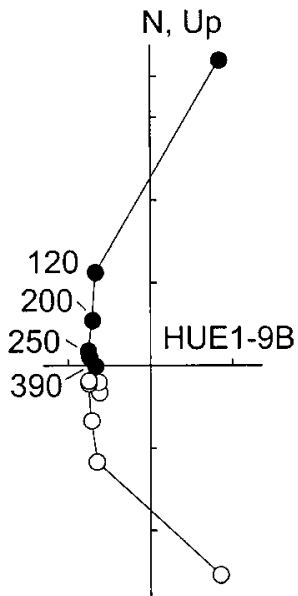

$\mathrm{NRM}=9.11 \mathrm{~mA} / \mathrm{m}$ 120

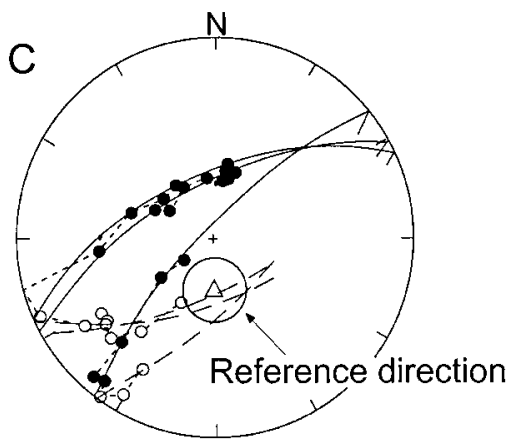

Fig. 5. A: Results of progressive thermal demagnetization of representative samples from clays of area B. Same symbols as in Fig. 3. B: Plot of the intensity decay curves during thermal treatment. Intensity is expressed as a normalized value $\left(\mathrm{M}[\mathrm{T}] / \mathrm{M}\left[20^{\circ} \mathrm{C}\right]\right)$. C: Equal-area, lower-hemisphere projection of demagneti-

ature component that is unambiguously resolved (Fig. 4, sample HUE1-6A). In this sample, the remanence remains stable at high temperature and has a well-defined southerly and upwards direction, i.e., a reversed magnetization. In this particular sample there is also a low-temperature northerly and downward direction component that parallels a normal geomagnetic field, not included in Figure 4 for clarity. zation end vectors for three samples. Note the convergence of the great circles towards a south and upwards magnetization direction, revealing an unresolved hightemperature reversed magnetization (reference direction by Parés and Pérez-González, 1995).

The limited number of samples displaying the unresolved HT component prevents the application of great-circle methods to determine its direction. Nonetheless, to judge from the demagnetization circles on a stereographic projection (Figs. 4, 5), there is a high-temperature component of reversed polarity.

We cannot determine the origin of remanent magnetization in the clays (i.e., chem- 


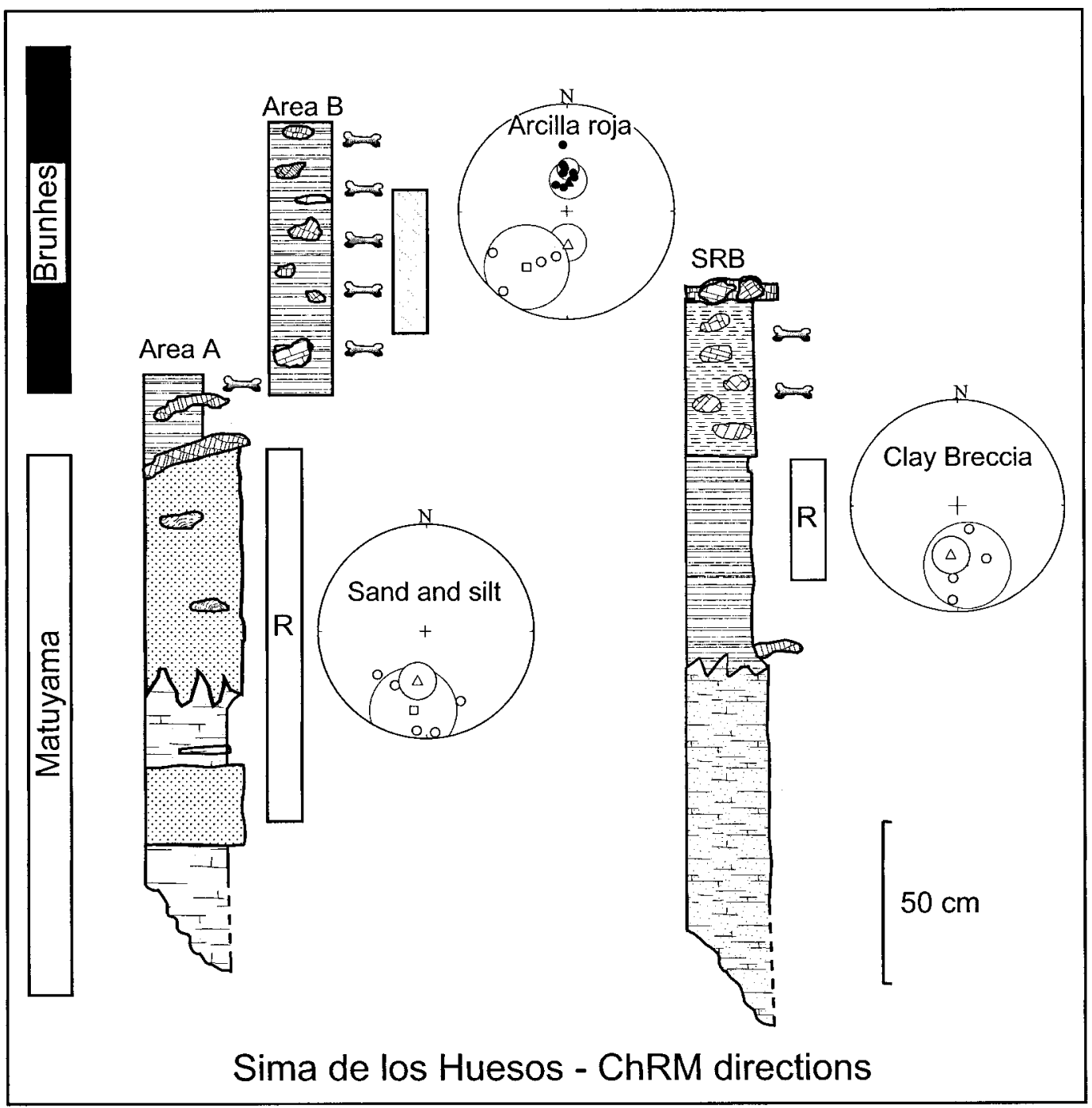

Fig. 6. Equal-area, lower-hemisphere stereographic projections of characteristic remanent magnetization (ChRM) directions for the studied units and corresponding magnetic polarity. Each symbol on the stereographic projections corresponds to an individual sample. Solid (open) symbols are projections onto the lower (upper) hemisphere and thus correspond to samples

ical vs. detrital). There are, however, numerous studies on clays from caves (Turner and Lyons, 1986; Lovlie and Sandnes, 1987; Papamarinopoulus et al., 1991; Valen et al., 1995) that show that reliable geomagnetic secular variation curves can be recovered. The existence of these smoothing curves indicates that the magnetization in cave clays with normal (reverse) polarity. Squares are the mean ChRM direction and they have the associated $95 \%$ confidence circles. The reversed directions (open symbols) show more scatter around the reference direction due to the contamination of the normal magnetic field. The triangles correspond to the reference direction (Parés and Pérez-González, 1995).

is stable, and that subsequent alteration of the magnetic signal is unlikely.

In summary (Fig. 6), the demagnetization data reveal that the sand and silt unit in the lower part of the stratigraphic section in area $\mathrm{A}$ (the base of the entire cave sequence so far exposed), and the clay breccia at section SRB, have a reversed magnetization. 
The overlying arcilla roja, the matrix of the breccia of hominid and bear bones, in both areas $\mathrm{A}$ and $\mathrm{B}$, has a dominant normal polarity magnetization. However, there is also evidence for a reverse polarity magnetization, and we interpret this as the primary magnetization.

\section{DISCUSSION}

The sand and silts exposed on the lower part of area A are considered to be the base of the entire cave-sequence so far exposed (Bischoff et al., 1997). Its extension across the Sima de los Huesos is unclear, and the lack of continuous exposure precludes correlation between the various excavated pits within the shaft. The top of the sand and silt unit is an irregular erosional surface, marked by the presence of a clast of a plate of fragile "cornflake" speleothem. Fragments of this speleothem are found within the next overlying 20-cm-thick hominidbearing clay (Fig. 1). U-series dating of these speleothem clasts gives an age in excess of $350 \mathrm{ka}$ (Bischoff et al., 1997); therefore, the underlying sand and silt should be older than that age. Given that they display reversed magnetization, the most conservative hypothesis is that the unit of sand and silts in the lower section of area A was deposited during the Matuyama Chron (>780 $\mathrm{ka}$. In addition, the reversed magnetization displayed by the clay breccia at section SRB would also suggest a Matuyama age for the deposit. The arcilla roja, which is the matrix for the breccia of human and bear bones, overlies the deposit in both areas A and B and is thus younger. As shown before, all fossil evidence shows that the arcilla roja has a Middle Pleistocene age. Thereafter, any normal polarity observed in the arcilla roja has to correspond to the Brunhes Chron. Thus, the traces of a reversed magnetization in the arcilla roja at areas $\mathrm{A}$ and $\mathrm{B}$ are an indication that some magnetization acquisition took place during a short reversed geomagnetic event within the Brunhes Chron. In the studied arcilla roja samples (areas A and B), it turns out that the LT component has normal polarity, whereas the HT is reversed. On the conservative assumption that the LT component is younger than the HT one, this implies that after the acquisition of the reverse HT component, the wet and unconsolidated mud having the LT component recorded a normal geomagnetic field. We think that at that stage, some magnetic grains were still able to rotate after the polarity reversal. The lock-in of the magnetization in sediments is a process that can take place over a period of thousands of years, longer than the duration of the magnetic polarity change. As a consequence, some of the particles deposited when the geomagnetic field is reversed may still be growing or reorienting when the geomagnetic field reverses its polarity to normal. In addition, the sediments with a primary reversed magnetization could also have been partially overprinted as a consequence of the ensuing higher-intensity normal geomagnetic field acting on the still unconsolidated sediment, by realigning some fraction of magnetic grains. Both the short duration and presumably low intensity of the geomagnetic field during the reversed event and diagenesis in the sediment explain how the reverse magnetization signal is obscured by the normal Brunhes magnetization. The existence of local areas of high porosity with indications of water drainage would probably restrict the zones with welldeveloped HT and LT components.

The Brunhes Chron (0-780 ka) appears to contain several short reversed-polarity events (e.g., Champion et al., 1988, 1996; Langereis et al., 1997; Lund et al., 1998). However only some of them have sufficient support to indicate that they may represent actual reversals of the geomagnetic field and not fluctuations of the geomagnetic intensity. For brevity, not all of these excursions can be discussed, and readers are referred to Champion et al. $(1988,1996)$ and Jacobs (1994). Within the interval of interest (780-200 ka) there are two recorded and well-documented excursions that could potentially explain our observations (see discussion on events within Brunhes in Langereis et al., 1997): namely, Calabrian Ridge 1 (CR1) (315-325 ka) and Jamaica/Pringle Falls (J/PF) (205-215 ka).

The older age of the arcilla roja given by the U-series dating, $320 \mathrm{ka}$ (Bischoff et al., 1997), is consistent with the age range of Ursus deningeri (Blackwell et al., 1990). 


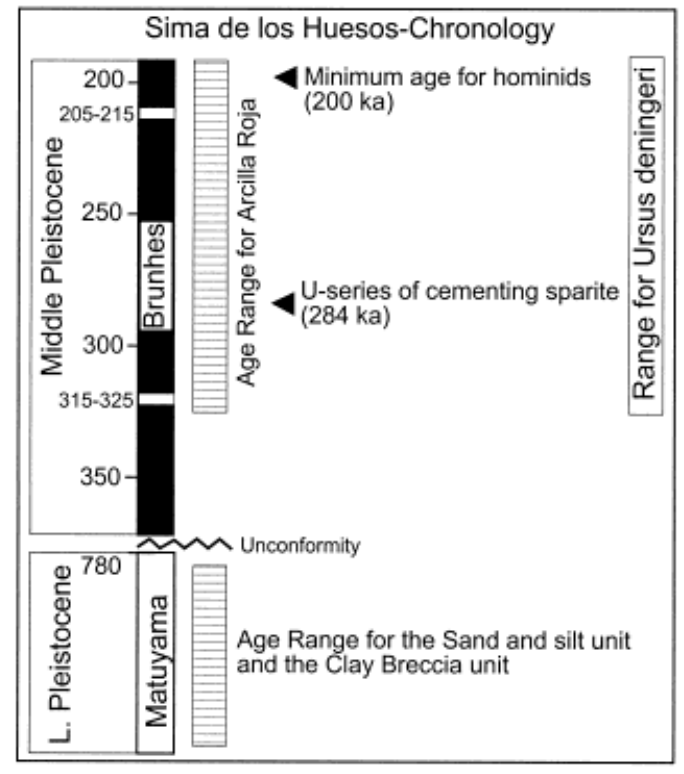

Fig. 7. Summary of chronological data for Sima de los Huesos. Black (white) boxes at left represent periods of normal (reversed) magnetization. Two geomagnetic events within Brunhes are indicated: Calabrian Ridge 1 (315-325 ka) and Jamaica/Pringle Falls (205-215 ka). Striped horizontal bars indicate the age range for both the arcilla roja and the sand and silt unit. The absolute ages for the human fossils are from U-series dating (Bischoff et al., 1997), as discussed in the text. The lower units at Sima de los Huesos (sand and silt and clay breccia) have reversed magnetization and thus have a Matuyama age, i.e., Lower Pleistocene.

The age of the arcilla roja is thus constrained between $780 \mathrm{ka}$ (the beginning of Brunhes Chron) and $200 \mathrm{ka}$ (the youngest age given by the U-series dating for the deposit) (Fig. 7).

A related question is the origin of the arcilla roja deposit. This deposit is characterized by a lack of bedding and a chaotic mixing and breaking of bones and speleothems. According to Bischoff et al. (1997), a karstic undermining caused collapse of the sediment package into the void, rotating and mixing in the process. Such a process would have serious implications for the paleomagnetic directions recorded in the arcilla roja. The postdepositional rotation and brecciation of the mud unit would have a randomizing effect on the magnetization directions. Our data show, however, that the magnetization directions are not scattered but are grouped (Fig. 6) in the stereographic projection. This grouping of the magnetization directions reveals that the clay deposit has not distorted subsequently to its deposition, ruling out the existence of a collapse of the unit that would produce a mixing process in the clays.

\section{CONCLUSIONS}

The paleomagnetic determinations indicate that the sand and silt (basement of the human-bearing clays) (area A) and the clay breccia (section SRB) have reversed magnetization, and thus the most conservative explanation is that they record the Matuyama epoch (Lower Pleistocene). The arcilla roja matrix of the hominid-bearing clay has an age of one of the Brunhes excursions (CR1 or J/PF), as indicated by reverse magnetization. The rodent fauna (A. bursae and Pliomys lenki relictus) seems to indicate an age of Saalian (OIS 8-7) (Cuenca-Bescós et al., 1997), whereas the carnivore fossils correlate with OIS 7 or older ( $>200$ ka) (García et al., 1997). On the other hand, the presence of Ursus deningeri constrains the age of the arcilla roja as no older than $315 \mathrm{ka}$. Therefore, either the CR1 or J/PF geomagnetic events may be responsible for the reversed magnetization in the arcilla roja, as both of them accommodate the U-series dating. Thus the age of the arcilla roja is either 205-325 or 315-325 ka. Further magnetic studies addressing the origin and delay of magnetization in endokarst clays will improve our understanding of the deposit and refine correlations between the endo- and exokarst deposits.

\section{ACKNOWLEDGMENTS}

Fieldwork in Atapuerca is supported by the Consejería de Cultura y Turismo (Junta de Castilla y León). This research was supported by DGES grants PB96-0815 and PB96-1026-C03, and by the Unidad Asociada CSIC-UCM. We thank our three anonymous reviewers for comments that led to the improvement of the manuscript. We are very grateful to the Edelweiss Speleological Group, and in particular to A.I. Ortega and M.A. Martín, for their constant help. 


\section{LITERATURE CITED}

Aguirre E, Arsuaga JL, Bermúdez de Castro JM, Carbonell E, Díez M, Enamorado J, Fernández-Jalvo Y, Gil E, Gracia A, Martín-Nájera A, Martínez I, Morales J, Ortega AI, Rosas A, Sánchez A, Sánchez B, Sesé C, Soto E, Torres TJ. 1990. The Atapuerca sites and the Ibeas hominids. J Hum Evol 5:55-73.

Arsuaga JL, Martínez I, Gracia A, Carretero JM, Carbonell E. 1993. Three new human skulls from the Sima de los Huesos Middle Pleistocene site in Sierra de Atapuerca, Spain. Nature 362:534-537.

Arsuaga JL, Martínez I, Gracia A, Carretero JM, Lorenzo C, García N, Ortega AI. 1997. Sima de los Huesos (Sierra de Atapuerca). The site. J Hum Evol 33:109-127.

Blackwell B, Schwarcz HP, Porat N, Howell FC, Arsebuk G. 1990. Electron spin resonance (ESR) dating of Ursus teeth from Yarimburgaz, Turkey. Geol Soc Am Abstr Programs 22:120-121.

Bischoff JL, Fitzpatrick JA, Leon L, Arsuaga JL, Falgueres C, Bahain JJ, Bullen T. 1997. Geology and preliminary dating of the hominid-bearing sedimentary fill of the Sima de los Huesos Chamber, Cueva Mayor of the Sierra de Atapuerca, Burgos, Spain. J Hum Evol 33:129-154.

Champion DE, Lanphere MA, Kuntz MA. 1988. Evidence for a new geomagnetic reversal from lava flows from Idaho: discussion of short polarity reversals in the Brunhes and Late Matuyama Polarity Chrons. J Geophys Res 93:11667-11680.

Champion DE, Lanphere MA, Anderson SR. 1996. Further verification and ${ }^{40} \mathrm{Ar} /{ }^{39} \mathrm{Ar}$ dating of the Big Lost reversed polarity subchron from drill core subsurface samples of the Idaho National Engineering Laboratory, Idaho. EOS Trans AGU 77:165.

Cuenca-Bescós G, Conesa CL, Canudo I, Arsuaga JL. 1997. Small mammals from Sima de los Huesos. J Hum Evol 33:175-190.

García N, Arsuaga JL, Torres T. 1997. The carnivore remains from the Sima de los Huesos Middle Pleistocene site (Sierra de Atapuerca, Spain). J Hum Evol 33:155-174

Jacobs JA. 1994. Reversals of the earth's magnetic field. Cambridge: Cambridge University Press. 346 p.

Kirschvink JL. 1980. The least-squares line and plane and the analysis of paleomagnetic data. Geophys $\mathrm{J} R$ Astronom Soc 62:699-718.

Langereis C, Dekkers M, de Lange GJ, Paterne M, van Santvoort PJM. 1997. Magnetostratigraphy and astronomical calbration of the last 1.1 Myr from an eastern Mediterranean piston core and dating of short events in the Brunhes. Geophys J Int 129:7594.
Lovlie R, Sandnes A. 1987. Paleomagnetic excursions recorded in mid-Weichselian cave sediments from Skjonghelleren, Valdery, Norway. Phys Earth Planet Int 45:337-348.

Lund SP, Acton G, Hastedt M, Okada M, Williams T, OPD Leg 172 Scientific Party. 1998. Geomagnetic field excursions occurred often during the last million years. EOS 79:178-179.

Martín MA, Domingo S, Antón T. 1981. Estudio de las cavidades de la zona BU-IV-A (Sierra de Atapuerca). In: KAITE Estudios de espelología burgalesa, Grupo Espeleológico Edelweiss, Burgos, Spain. p 41-75.

Olivé A, Ramirez Merino JL, Ortega LI. 1990. Mapa geológico de España a escala 1:50,000 (Belorado, 201). Madrid: I.T.G.E.

Papamarinopoulos S, Readman PW, Maniatis Y, Simopoulos A. 1991. Palaeomagnetic and mineral magnetic studies of sediment from Ball's Cavern, Schoharie, USA. Earth Planet Sci Lett 102:198-212.

Parés JM, Pérez-González A. 1995. Paleomagnetic age for hominid fossils at Atapuerca archaeological site, Spain. Science 269:830-832.

Pérez-González A, Aleixandre T, Pinilla A, Gallardo J, Benayas J, Martínez MJ, Ortega AI. 1995. An approach to the Galeria stratigraphy in the Sierra de Atapuerca trench (Burgos). In: Bermúdez de Castro JM, Arsuaga JL, Carbonell E, editors. Human evolution in Europe and the Atapuerca evidence. Valladolid, Spain: Junta de Castilla y León, Consejería de Cultura y Turismo. p 99-122.

Pineda A, Arce JM. 1997. Mapa geológico de España a escala 1:50,000 (Burgos, 200). Madrid: I.T.G.E.

Torres TJ. 1976. El karst de la Sierra de Atapuerca. Cuad Arqueol Deusto 1:13-15.

Turner G, Lyons RG. 1986. A paleomagnetic secular variation record from c. 120,000 yr-old New Zealand cave sediments. Geophys J R Astronom Soc 87:11811192.

Valen V, Larsen E, Mangerud J. 1995. High-resolution paleomagnetic correlation of Middle Weichselian icedammed lake sediments in two coastal caves, western Norway. Boreas 24:141-153.

Zazo C, Goy JL, Hoyos M. 1987. Contexto geológico y geomorfológico. In: Aguirre E, Carbonell E, Bermúdez de Castro JM, editors. El hombre fósil de Ibeas y el Pleistoceno de la Sierra de Atapuerca. Valladolid, Spain: Junta de Castilla y León. p 41-46.

Zazo C, Goy JL, Hoyos M. 1983. Estudio geomorfológico de los alrededores de la Sierra de Atapuerca (Burgos). Estud Geol 39:179-185.

Zijderveld JDA. 1967. AC demagnetization of rocks: analysis of results. In: Collinson DW, Runcorn SK, Creer KM, editors. Methods in paleomagnetism. New York: Elsevier. p 254-286. 